\title{
PENGGUNAAN LABORATORIUM MATEMATIKA SEBAGAI SUMBER BELAJAR MAHASISWA: STUDI KASUS DI LABORATORIUM MATEMATIKA IAIN MATARAM
}

\author{
Uswatun Hasanah ${ }^{1}$, Susilahudin Putrawangsa ${ }^{2}$, Siti Hikmatussani ${ }^{2}$ \\ 1STMIK Bumigora Mataram, Jalan Ismail Marzuki Mataram, Indonesia 83000 \\ 2Fakultas Ilmu Tarbiyah dan Keguruan IAIN Mataram, Jalan Gajah Mada No. 100 Mataram, Indonesia \\ Email: uswaalhasana44@gmail.com
}

\begin{abstract}
Abstrak
Penelitian ini bertujuan untuk menggambarkan penggunaan laboratorium matematika sebagai sumber belajar mahasiswa di Jurusan Pendidikan Matematika IAIN Mataram. Penelitian ini merupakan penelitian kualitatif deskriptif dengan pendekatan studi kasus. Adapun sumber data dalam penelitian ini adalah ketua jurusan pendidikan matematika, pengelola laboratorium, pembina coassisten praktikum dan mahasiswa praktikan serta dokumen kegiatan praktikum. Data dalam penelitian ini dikumpulkan dengan teknik wawancara yang didukukng dengan teknik observasi, angket dan dokumentasi. Hasil penelitian ini menunjukkan bahwa pemanfaatan laboratorium sebagai sumber belajar mahasiswa cukup baik jika mengacu pada indikator yang telah ditentukan meskipun ada beberapa hambatan dalam pemanfaatannya. Selain itu, di dalam penelitian ini ditemukan juga beberapa alternatif untuk menanggulangi hambatan tersebut sehingga bisa mewujudkan sebuah laboratorium matematika yang dapat menunjang pencapaian tujuan pembelajaran.
\end{abstract}

Kata kunci: Laboratorium Matematika, Sumber Belajar.

\begin{abstract}
The recent study intends to describe the usefulness of mathematics laboratory as learning resource for students at Mathematics Department IAIN Mataram. It is a qualitative descriptive research. The finding shows that the laboratory has been used relatively well as learning resource for students even though there are some obstacles faced by students. It is also found some alternate solutions to address the obstacles in order to maximize the usefulness of laboratory as learning resource.
\end{abstract}

Keywords: Mathematics Laboratory, Learning Resource.

\section{PENDAHULUAN}

Pendidikan sebagai salah satu tri darma perguruan ini yang bertujuan untuk meningkatkan dan mengembangkan sumber daya manusia. Oleh karena itu menurut Hummel tujuan pendidikan setidaknya harus mengandung tiga nilai yaitu, autonomy, equity dan survival. Autonomy yaitu 
memberi kesadaran, pengetahuan dan kemampuan secara maksimum kepada individu maupun kelompok untuk dapat hidup mandiri dan bersama ke arah kehidupan yang lebih baik. Equity, artinya memberi kesempatan kepada seluruh warga masyarakat untuk dapat berpartisipasi dalam kehidupan berbudaya dan ekonomi dengan memberikan pendidikan yang baik, berguna dan bermanfaat sebagai sarana dan bekal menuju ke arah itu. Survival berarti dengan pendidikan akan menjamin pewarisan budaya dari satu generasi ke generasi berikutnya. ${ }^{1}$

Sejalan dengan perkembangan dunia pendidikan yang semakin pesat maka perguruan tinggi harus dapat menyesuaikan dengan perkembangan ilmu pengetahuan, sehingga diperlukan perhatian khusus untuk menghadapi perkembangan dan kemajuan pendidikan guna meningkatkan mutu dan kualitas pendidikan². Bentuk perhatian pemerintah dalam menghadapi perkembangan dunia pendidikan dapat dilihat dari kegiatan terpadu dan berkesinambungan seperti upaya penyempurnaan kurikulum, peningkatan kualitas guru, pengadaan buku, alat peraga, penyediaan dana untuk saran dan prasarana dan lain-lain.

Berdasarkan tujuan pendidikan yang telah dijelaskan sebelumnya maka perguruan tinggi sebagai lembaga pendidikan membutuhkan unsur-unsur penunjang terlaksananya proses belajar mengajar antara lain tersedianya laboratorium $^{3}$ sebagai tempat untuk mengadakan pengamatan dan pembuktian teori-teori. Laboratorium sebagai pusat kegiatan dosen dan mahasiswa melakukan kegiatan belajar mengajar untuk memantapkan pengetahuannya.

Laboratorium matematika merupakan media instruksional edukatif yang berfungsi untuk melatih keterampilan mahasiswa dalam menyelesaikan persoalan matematika karena matematika merupakan salah satu mata kuliah pokok yang harus dipelajari untuk meningkatkan keterampilan mahasiswa

\footnotetext{
${ }^{1}$ Usman, 2010

${ }^{2}$ Isjoni, 2009

${ }^{3}$ Departemen Pendidikan Nasional, 2002
} 
dan pengelolaannya dilakukan oleh jurusan pendidikan matematika sebagai salah satu sumber belajar. Sebagi contoh, tersedia berbagai program pengembangan aplikasi pembelajaran matematika komputasi dan alat-alat peraga yang bisa digunakan dan dikembangkan oleh mahasiswa. Akan tetapi, budaya memanfaatkan laboratorium matematika di kalangan mahasiswa secara umum masih jauh dari harapan. Hal ini dapat terlihat pada tabel 1 berikut ini:

Tabel 1.

Persentasi Kehadiran Mahasiswa Praktikum Laboratorium Semester V

\begin{tabular}{|c|c|c|c|}
\hline No & Kelas/Semester & Jumlah Mahasiswa & Persentasi kehadiran \\
\hline 1 & VA & 34 & $41,17 \%$ \\
\hline 2 & VB & 35 & $37,14 \%$ \\
\hline 3 & VC & 35 & $45,71 \%$ \\
\hline 4 & VD & 41 & $26,82 \%$ \\
\hline
\end{tabular}

Pada Tabel 1 dapat menunjukkan bahwa budaya memanfaatkan laboratorium matematika oleh mahasiswa semester $\mathrm{V}$ masih rendah dan belum bisa secara maksimal memanfaatkan segala fasilitas yang ada di Laboratoriummatematika sebagai sumber belajar.

\section{METODE}

\section{Pendekatan Penelitian}

Penelitian ini menggunakan pendekatan penelitian kualitatif ${ }^{4}$ karena data-data yang diperoleh di lapangan lebih bersifat informasi yang diperoleh melalui wawancara atau observasi, bukan dalam bentuk angka atau simbol. Peneliti menggunakan desain penelitian kualitatif dengan pendekatan deskriptif ${ }^{5}$ dalam bentuk studi kasus artinya data yang dikumpulkan di lapangan akan dianalisis yang didukung oleh hasil pengamatan yang komfrehensif mengenai pemanfaatan laboratorium sebagai sumber belajar mahasiswa pendidikan matematika.

${ }^{4}$ Ansel Strauss \& Juliet Corbin, 2009

${ }^{5}$ Arief Furchan, 2007 


\section{Kehadiran Peneliti}

Kehadiran peneliti diperlukan untuk memperoleh data terhadap hasil penelitian yang dilakukan. Oleh sebab itu, peneliti berusaha menciptakan hubungan akrab dengan responden sebagai sumber data agar data yang diperoleh valid. Kehadiran peneliti merupakan hal yang sangat penting agar peneliti dapat melihat langsung dan menggali obyekobyek yang berkaitan dengan penelitian.

Berdasarkan konteks penelitian yang dilakukan yaitu mencoba menemukan fenomena-fenomena yang berkaitan dengan pemanfaatan laboratorium sebagai sumber belajar mahasiswa sehingga kehadiran peneliti merupakan instrumen kunci dalam mengumpulkan data dan dituntut untuk memiliki ketajaman analisis dalam melihat peristiwaperistiwa yang terjadi di lokasi penelitian.

\section{Lokasi Penelitian}

Penelitian ini dilakukan di laboratorium matematika IAIN Mataram yang berlokasi di Jalan Gajah Mada No 100 Jempong Mataram tepatnya di Gedung B lantai II. Tempat ini menyediakan 22 unit komputer untuk praktikan dan 1 unit komputer di ruangan khusus untuk pelayanan kegiatan praktikum oleh pengelola lab. Selain itu, berbagai macam alat peraga tersusun rapi yang didukung oleh modul pembuatan alat peraga.

\section{Sumber Data}

Sumber data ${ }^{6}$ yang dijadikan sebagai informan mengenai pemanfaatan Laboratoriumadalah:

a. Ketua jurusan pendidikan matematika merupakan penanggungjawab laboratorium matematika dan mengetahui perkembangan lab.

b. Para pembina praktikum pada mahasiswa semester V jurusan pendidikan matematika

c. Pengelola Laboratoriumyang mengetahui secara langsung perkembangan paraktikum

${ }^{6}$ Suharsimi Arikunto, 2006 
d. Semua co ass praktikum yang langsung membimbing mahasiswa semester V

e. Perwakilan 12 orang mahasiswa semester VA, VB, VC, VD

\section{Teknik Pengumpulan Data}

Adapun teknik yang digunakan dalam mengumpulkan data yaitu:

a. Teknik observasi ${ }^{7}$, mengobservasi langsung kegiatan praktikum di lab

b. Teknik interview (wawancara), melakukan wawancara terhadap sumber data menggunakan metode wawancara bebas terpimpin artinya peneliti mengikuti arah wawancara dengan menggunakan pedoman yang berisi tentang permasalahan yang diteliti. Akan tetapi peneliti tetap mengarahkan terwawancara dengan menggunakan pedoman sebagai pengendali agar pembicaraan tidak menyimpang dari permasalahan.

c. Dokumentasi

d. Angket

\section{Teknik Analisis Data}

Langkah-langkah analisis data meliputi pertama persiapan, yakni mengecek kembali sumber data yang dihubungi untuk kelayakan pertanggungjawaban dan mengecek kelengkapan data yang telah dikumpulkan dari lokasi. Kedua, mengelompokkan atau menggenerasisasikan data-data yang telah dikumpulkan di lokasi penelitian. Ketiga, perumusan data sesuai dengan permasalahan penelitian

Validasi data dilakukan untuk menjamin keabsahan data yang telah dikumpulkan. Triangulasi ${ }^{8}$ data merupakan kegiatan membandingkan hasil wawancara antara responden yang berkaitan dengan permasalahan yang diteliti.

${ }^{7}$ M. Subana dan Sudrajat, 2001

${ }^{8}$ Lexy Moleong, 2010 


\section{HASIL DAN PEMBAHASAN}

\section{Gambaran Umum Laboratorium Pendidikan Matematika}

Laboratorium pendidikan matematika IAIN Mataram terdiri atas dua ruangan yaitu ruangan koordinator dan ruang praktikum komputasi. Ruang koordinator menyediakan 1 unit komputer dan 22 unit komputer tersedia di ruang praktikan yang dilengkapi dengan beberapa perabotan lainnya yaitu meja dan kursi praktek, LCD, monitor dan whiteboard serta menyediakan alat peraga lainnya. Adapun program aplikasi yang biasa digunakan dalam praktikum yaitu Operating Sistem (Windows XP dan Windows 7), software statistik (SPSS, MINITAB), matematika (MATLABORATORIUM, MAPLE), program (C++, ITEMAN, QS, DELPHI), editor (office), graphics (Corel Draw, Photoshop) dan software-software lainnya.

Laboratorium matematika bertujuan agar pengetahuan mahasiswa bersifat paripurna antara teori dan praktek sehingga mahasiswa bisa menciptakan modeling-modeling atau mendapatkan teori dan bisa mengaplikasikan matematika. Selain itu, Laboratoriumini dijadikan sebagai tempat mengkaji materi-materi matematika yang berkaitan dengan aplikasinya dan bisa mempraktikannya berdasarkan muatan matematika yang bersifat aplikatif yang cenderung berhubungan dengan matematika komputasi.

Berbeda halnya dengan pengertian laboratorium secara umum, namun Laboratoriummatematika dalam hal ini disebut dengan ruangan yang dengan metode praktikum yang akan mengajarkan suatu kompetensi komputasi matematika dengan cara mahasiswa mendapatkan pemahaman tentang kompetensi tersebut melalui kegiatan kerja dengan prosedur kerjanya sudah terkonstruksi dalam suatu alur kerja. Laboratorium sekurang-kurangnya memiliki tiga bagian yaitu laboratorium Komputasi dan Simulasi, tempat melatih mahasiswa membuat aplikasi program matematika dan statistik seperti 
Matlaboratorium, Delphi, C++ dan lain-lain. Laboratorium Riset Operasi sebagai tempat melatih mahasiswa menggunakan aplikasi program matematika yang berbasis windows seperti SPSS, Minitab, QS, Fluent dan lain-lain dan Laboratorium pendidikan matematika tempat membangun berbagai alat atau media pembelajaran.

\section{Proses Pelaksanaan Praktikum di Laboratorium}

Ada beberapa langkah atau strategi yang dilakukan dalam kegiatan praktikum di laboratorium pendidikan matematika yaitu:

a. Pembuatan modul praktikum yang dikembangkan dari materi kuliah yang ditempuh saat itu oleh mahasiswa

b. Pengumpulan modul dilatihkan kepada Coassisten

c. Mahasiswa melaksanakan praktikum yang sesuai dengan petunjuk kerja dalam modul di bawah bimbingan Coassisten

d. Diberikan lembar kerja praktikum untuk diisi mahasiswa sebagai record hasil komputasi dan simulasi yang dijalankan

e. Diberikan tugas sesuai dengan kompetensi dasar yang harus dicapai

f. Dilaksanakan evaluasi pada akhir kegiatan praktikum

\section{Pemanfaatan Laboratorium Matematika Sebagai Sumber Belajar}

\section{Mahasiswa}

Laboratorium yang ideal di jurusan pendidikan matematika terdiri atas empat bagian yaitu laboratorium dasar, laboratorium pengembangan, laboratorium metodologi dan laboratorium penelitian. Namun dalam hal ini, laboratorium pendidikan matematika di perguruan tinggi bisa digunakan sebagai tempat melakukan kegiatan workshop di bawah bimbingan dosen untuk menciptakan alat-alat peraga pengajaran matematika dan berlatih menggunakannya sehingga mahasiswa sebagai calon guru bisa memantapkan pengetahuannya tentang obyek-obyek matematika. Di Laboratoriumini dosen bersama mahasiswa bisa bekerja sama dalam kegiatan penelitian yang terkait dengan matematika komputasi yang didukung oleh berbagai macam buku referensi 
penunjang matematika. Selain itu, sebaiknya ruangan Laboratoriumini menyediakan sejarah/biografi tokoh matematika dan penemuannya karena merupakan tempat sumber belajar matematika.

Jurusan pendidikan matematika IAIN Mataram memiliki Laboratoriumyang menyediakan berbagai fasilitas yang bisa dimanfaatkan oleh dosen dan mahasiswa sebagai sumber belajar tetapi kurang bisa dioptimalkan oleh mahasiswa dan dosen sebagai sumber belajar. Pemanfaatannya juga sebatas sebagai tempat praktikum komputasi saja. Kegiatan lainnya tidak terlalu diprioritaskan seperti kegiatan workshop alat peraga, penelitian dan lain-lain. Ruangan ini hanya menyediakan CD software, modul, baju praktikum tetapi tidak menyediakan buku-buku matematika, lembar tugas, lembar kerja, slide, dan buku referensi lainnya.

Kegiatan praktikum komputasi di Laboratoriumdiprioritaskan di Laboratoriumuntuk dimanfaatkan sebagai tempat mengembangkan mahasiswa artinya mahasiswa mampu mengaplikasikan materi matematika saja karena efek dari praktikum komputasi adalah mahasiswa bisa menyelesaikan masalah matematika dengan menggunakan komputer atau dapat mengkroscek jawabannya yang diselesaikan secara manual. Contohnya, mencari akar persamaan fungsi $\mathrm{f}(\mathrm{x})=\mathrm{xe}^{-\mathrm{x}}+1$, akan mustahil dikerjakan secara manual tanpa bantuan komputer. Dengan menggunakan algoritma yang didefinisikan dalam program komputer akan membantu mahasiswa dalam melakukan komputasi. Dengan bantuan perangkat lunak MatLaboratoriummahasiswa bisa menyelesaikan permasalahan tersebut.

Selain mempelajari Matlaboratorium, mahasiswa diperkenalkan dengan Macromedia Flash yang melatih mahasiswa dalam pembuatan media pembelajaran yang menyenangkan dengan berbagai animasi unik. Adapun alat peraga yang akan dimanfaatkan di Laboratoriumyaitu papan lantai bilangan, mesin logika, philing, kolom perkalian dan lain 
sebagainya yang memiliki fungsi masing-masing berdasarkan materi yang diajarkan di sekolah.

\section{Hambatan-hambatan dalam Pemanfaatan Laboratorium Pendidikan Matematika dan Alternatif Penanggulangnnya}

Ada beberapa hambatan yang terjadi dalam pemanfaatan Laboratoriumdi jurusan pendidikan Matematika yang membutuhkan perhatian khusus dari pihak pengelola yaitu sikap ketidakpedulian mahasiswa dalam mengiikuti praktikum yang tidak masuk ke dalam SKS perkuliahan sehingga tidak mempengaruhi Indeks Prestasinya. Hal demikian diperlukan adanya tindakan tegas dari pihak laboran seperti salah satunya proses pelaksanaan praktikum digunakan sebagai pertimbangan untuk menentukan nilai akhir mahasiswa. Dalam hal ini diperlukan intervensi dari pihak jurusan dan dosen pengampu mata kuliah yang dipraktikkan pada setiap semester untuk memotivasi mahasiswa akan pentingnya kegiatan praktikum.

Sarana dan prasarana terutama komputer yang tersedia di Laboratoriumjuga sangat minim jumlahnya yang tidak sesuai dengan jumlah mahasiswa praktikum sehingga menjadi salah satu alasan mahasiswa untuk tidak megikuti kegiatan praktikum. Persediaan daya listrik dan modul berkurang menjadi salah satu penghambat berjalannya proses kegiatan praktikum. Selain itu, pemahaman konsep matematika mahasiswa masih $\leq 80 \%$ menyebabkan proses pembuatan algoritma komputasi menjadi sulit. Hal ini dilihat dari hasil evaluasi mahasiswa yang dilakukan setiap akhir praktikum. Kebanyakan mahasiswa belum menguasai konsep matematika yang akan dipraktikkan sehingga pada saat praktikum mahasiswa kesulitan membangun algoritma komputasi. Menanggapi pernyataan tersebut diperlukan adanya peningkatan penguasaan konsep matematika mahasiswa dilakukan dengan mengembangkan modul/materi praktikum yang memuat konsep materi kuliah yang ditempuh pada saat itu. Dengan demikian, modul praktikum 
bisa disusun berdasarkan materi terdekat yang pernah dipelajari mahasiswa.

Laboratorium pendidikan matematika IAIN Mataram juga belum memiliki desain instruksional materi praktikum yang terkonstruksi dengan materi-materi kuliah lainnya. Hal ini membuat mahasiswa sulit terkoneksi pada saat praktek. Oleh karena itu, setidaknya diadakan sejenis pamplet untuk memperkenalkan kelebihan dari mata kuliah yang akan dijalankan dan mahasiswa diberikan waktu untuk membiasakan diri dalam mengoperasikan komputer sebelum menjelaskan materi praktikum.

Selain itu, diperlukan danya workshop dosen pembina mata kuliah dan praktikum untuk mengkonstruksi desain instruksional yang membahas kompetensi yang harus dicapai agar terhubung dengan materi kuliah di kelas. Kegiatan sejenis ini tidak pernah dilakukan oleh pihak jurusan sehingga berakibat pada mahasiswa yang tidak sepenuhnya bisa terkoneksi dengan materi praktikum.

Pembuatan tata tertib Laboratoriumyang dapat mengarahkan pencapaian Kompetensi Dasar juga perlu diadakan. Akan tetapi, tata tertib di Laboratoriumtidak dilaksanakan sepenuhnya oleh mahasiswa karena tidak ada informasi atau pemberitahuan tata tertib yang berlaku. Selanjutnya masalah kabel LAN pada jaringan kompuetr sudah tersedia di lab. Hal ini dilakukan agar dapat dilakukan interaksi file antar komputer, tetapi tidak bisa berfungsi karena komputer selalu aktif dari pagi sampai sore diakibatkan karena padatnya jadwal mahasiswa yang praktikum dan hardisk komputer yang tidak layal untuk digunakan. Satu hal yang perlu dilakukan juga sebelum diadakan kegiatan praktikum yaitu diadakan asistensi mahasiswa terutama terkait konsep matematika yang akan dipraktikumkan dan dilaksanakan evaluasi asistensi awal tersebut. 


\section{SIMPULAN}

Teknis pemanfaatan laboratorium pendidikan matematika cukup baik dijadikan sumber belajar mahasiswa jika mengacu pada indikator yang telah ditentukan. Dari segi penggunaannya, laboratorium pendidikan matematika IAIN Mataram berproses secara terus menerus dan berkesinambungan dalam memberikan pengembangan skill di bidang teknologi dan pemrograman melalui kegiatan praktikum yang telah terjadwal sebelumnya. Mahasiswa diperkanalkan materi dalam modul yang telah dikembangkan dari materi kuliah yang ditempuh, selanjutnya diberikan pelatihan sesuai petunjuk kerja, pemberian tugas dan diakhiri dengan evaluasi. Kegiatan penelitian, pembuatan alat peraga dan pengembangan media pembelajaran matematika dapat dioptimalkan pelaksanaannya di laboratorium yang akan dijadikan referensi bagi mahasiswa selanjutnya.

Ada beberapa hambatan dalam memanfaatkan laboratorium sebagai sumber belajar mahasiswa yaitu:

a. Penguasaan konsep matematika mahasiswa masih $\leq 80 \%$ yang menyebabkan proses pembuatan algoritma komputasi menjadi sulit.

b. Daya listrik yang kurang sehingga menyebabkan proses praktikum terganggu

c. Belum memiliki desain instruksional materi praktikum yang terkonstruksi dengan materi-materi kuliah lainnya

d. Komputer belum terkoneksi dengan LAN sehingga pemindahan file hasil praktikum sebelumnya ke komputer yang digunakan mahasiswa tidak efisien karena secara manual dengan flasdisc akan berpotensi membawa virus.

e. Minat sebagian mahasiswa mengikuti praktikum masih berkurang.

Untuk menanggulangi hambatan tersebut, diperlukan beberapa alternatif untuk menanggulanginya yaitu antara lain: 
a. Peningkatan penguasaan konsep matematika mahasiswa dilakukan dengan mengembangkan modul/materi praktikum yang memuat konsep materi kuliah yang sedang ditempuh

b. Peminjaman laptop atau mengganti jadwal praktikum untuk mengatasi daya listrik yang kurang. Untuk masalah penjadwalan ini, sistem penjadwalan seperti yang rancangan Hasanah \& Putrawangsa (2015) dapat dijadikan solusi. ${ }^{9}$

c. Mendesain ulang beberapa kompetensi dasar materi praktikum tiap semester untuk mendapatkan bentuk instruksional yang optimal

d. Membuat pemetaan kompuetr yang digunakan mahasiswa

e. Diadakan sejenis pamplet untuk memperkenalkan kelebihan dari mata kuliah yang akan dijalankan dan adanya tindakan tegas dari pihak laboran atau jurusan terhadap mahasiswa yang masih acuh terhadap kegiatan praktikum.

\section{PENGAKUAN/ACKNOWLEDGMENTS}

Terima kasih kepada pihak jurusan matematika seperti ketua jurusan, kepala laboratorium, laboran laboratorium, dosen pembina mata kuliah praktikum semester V, Coassisten, dan perwakilan mahasiswa yang ikut andil dalam proses pengumpulan data.

\section{DAFTAR PUSTAKA}

Ansel Strauss \& Juliet Corbin. Dasar-Dasar Penelitian Kualitatif. Yogjakarta: Pustaka Belajar Offset,2009

Arief Furchan. Pengantar Penelitian dalam Pendidikan. Yogjakarta: Pustaka Pelajar,2007

Departemen Pendidikan Nasional. Kamus Besar Bahasa Indonesia. Jakarta: Balai Pustaka, 2002

9 Hasanah \& Putrawangsa, 2015. Penggunaan Aljabar Maxplus dalam Pembentukan Model Matematispada Sistem Penjadwalan Praktikum Laboratorium. Jurnal Beta Vol. 8 No. 1 hal. 75-88 
Hasanah \& Putrawangsa, 2015. Penggunaan Aljabar Maxplus dalam Pembentukan Model Matematispada Sistem Penjadwalan Praktikum Laboratorium. Jurnal Beta Vol. 8 No. 1 hal. 75-88

Isjoni. Pembelajaran Kooperatif. Yogjakarta: Pustaka Belajar, 2009

Lexy Moleong,. Metode Penelitian Kualitatif. Bandung:Rosdakarya,2010

M. Subana dan Sudrajat. Dasar-dasar Penelitian Ilmiah. Bandung: Pustaka Setia,2001

Suharsimi Arikunto. Prosedur Penelitian Suatu Pendekatan Praktik. Jakarta: PT Rineka Cipta, 2006

Usman. Tasqif Pendidikan dalam Kerangka Direktif dan Prediktif, Jurnal Pemikiran, Paradigma dan Penelitian Pendidikan, No. 1 Vol. 8,2010 